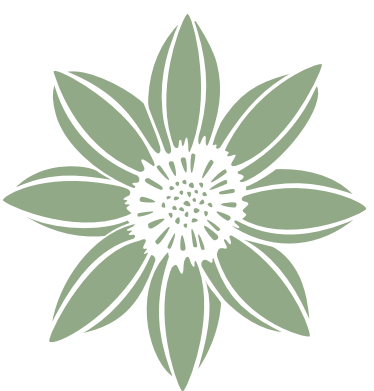

Acta Botanica Mexicana
Antibacterial activity and phenolic profile of the methanolic extract from the aerial parts of Hyptis suaveolens (Lamiaceae)

\title{
Actividad antibacteriana y perfil fenólico del extracto metanólico de las partes aéreas de Hyptis suaveolens (Lamiaceae)
}

\author{
Israel Bonilla-Landa' (D), José María Callejas-Linares², (D), Elvis Marian Cortazar-Murillol (iD, Feliza Ramón Farías',3 (D), \\ Marina Guevara-Valencia2 (D), Juan Luis Monribot-Villanueva1,4 (D), José Antonio Guerrero-Analco',4 (D)
}

\begin{abstract}
:
Background and Aims: Hyptis suaveolens is a well-known plant in Latin America for its medicinal properties. Despite its diverse uses in traditional medicine, there are few reports concerning its chemical composition. In addition, the antimicrobial activity against human-pathogen bacteria is known, but there are few reports about its activity on phytopathogenic bacteria, specifically for those affecting important crops. In this context, the main aims of this work were to determinate the antibacterial activity of $H$. suaveolens leaves on phytopathogenic bacteria, and their phenolic profile, in order to contribute to the knowledge of the phytochemical composition and bioactivity of $\mathrm{H}$. suaveolens for phytosanitary applications.

Methods: The plant material was collected, and the aerial parts were dried, milled, and extracted with methanol. The crude extract was tested against two phytopathogenic bacterial strains (Chryseobacterium sp. and Pseudomonas sp.). Finally, phenolic compounds were identified and quantified using ultra-high performance liquid chromatography coupled with mass spectrometry.

Key results: The crude extract of $H$. suaveolens exhibited a moderate antibacterial activity against Chryseobacterium sp., and 14 phenolic compounds were identified and quantified, highlighting rosmarinic acid, which showed the highest concentration followed by quercetin-3-glucoside and rutin. Six phenolic compounds were identified and quantified for the first time in $\mathrm{H}$. suaveolens.

Conclusions: In this work, the antibacterial activity of $H$. suaveolens leaves was demonstrated and it may correlate with the identification and quantification of 14 phenolic compounds, particularly with the presence of rosmarinic acid.
\end{abstract}

Key words: antimicrobial activity, mass spectrometry, phenolics.

\section{Resumen:}

Antecedentes y Objetivos: Hyptis suaveolens es una planta bien conocida en América Latina por sus propiedades medicinales. A pesar de sus diversos usos en la medicina tradicional, hay pocos reportes de su composición química. Además, se conoce su actividad contra bacterias que afectan al ser humano, pero existen pocos reportes acerca de su actividad sobre bacterias fitopatógenas, específicamente sobre aquellas que afectan cultivos. En este contexto los principales objetivos de este trabajo fueron determinar la actividad antibacteriana de hojas de $\mathrm{H}$. suaveolens en bacterias fitopatógenas y su perfil fenólico, con el fin de contribuir al conocimiento de la composición fitoquímica y bioactividad de $\mathrm{H}$. suaveolens para aplicaciones fitosanitarias.

Métodos: El material vegetal fue colectado y las partes aéreas se secaron, molieron y extrajeron con metanol. El extracto crudo fue probado contra dos cepas bacterianas fitopatógenas (Chryseobacterium sp. y Pseudomonas sp.). Finalmente, se identificaron y cuantificaron compuestos fenólicos utilizando cromatografía de líquidos de ultra alta resolución acoplada a espectrometría de masas.

Resultados clave: El extracto crudo de H. suaveolens mostró una actividad antibacteriana moderada en contra de Chryseobacterium sp., y se identificaron y cuantificaron 14 compuestos fenólicos, destacando al ácido rosmarínico, el cual mostró ser el más abundante, seguido de quercetina3-glucósido y rutina. Seis compuestos fenólicos fueron identificados y cuantificados por primera vez en $\mathrm{H}$. suaveolens.

Conclusiones: En este estudio se demostró la actividad antibacteriana de las hojas de $H$. suaveolens y su correlación con la identificación y cuantificación de 14 compuestos fenólicos, particularmente con la presencia del ácido rosmarínico.

Palabras clave: actividad antimicrobiana, compuestos fenólicos, espectrometría de masas.

${ }^{1}$ Instituto de Ecología, A.C. (INECOL), Clúster Científico y Tecnológico BioMimic ${ }^{\circledast}$, Red de Estudios Moleculares Avanzados, Carretera Antigua a Coatepec No. 351, Colonia El Haya, 91070 Xalapa, Veracruz, Mexico.

${ }^{2}$ Universidad Veracruzana, Facultad de Ciencias Químicas, Prolongación Oriente 6. No. 1009, 94340 Orizaba, Veracruz, Mexico.

${ }^{3}$ Universidad Veracruzana, Facultad de Ciencias Biológicas y Agropecuarias, Carretera Peñuelas - Amatlán km 177, 94500 Córdoba, Veracruz, Mexico.

${ }^{4}$ Authors for correspondence: juan.monribot@inecol. mx, joseantonio.guerrero@inecol.mx
Received: July 8, 2021.

Reviewed: November 17, 2021.

Accepted by Marie-Stéphanie Samain: December 1 , 2021

Published Online first: January 18, 2022

Published: Acta Botanica Mexicana 129 (2022).

cC) (1) This is an open access article under the Creacc) tive Commons 4.0 Attribution-Non commercial Licence (CC BY-NC 4.0 International)
To cite as: Bonilla-Landa, I., J. M. Callejas-Linares, E. M. Cortazar-Murillo, F. Ramón Farías, M. GuevaraValencia, J. L. Monribot-Villanueva and J. A. Guerrero-Analco. 2022. Antibacterial activity and phenolic profile of the methanolic extract from the aerial parts of Hyptis suaveolens (Lamiaceae). Acta Botanica Mexicana 129: e1920. DOI: https://doi.org/10.21829/ abm129.2022.1920

e-ISSN: 2448-7589 


\section{Introduction}

The genus Hyptis Jacq. belongs to the family Lamiaceae and includes more than 290 species with distribution in the Neotropics (Luzuriaga-Quichimbo et al., 2018). This genus has attracted the attention of many research groups because of its biological activities, including antioxidant, anti-inflammatory, antimicrobial, antiviral, and anticancer compounds (Bezerra et al., 2017; Luzuriaga-Quichimbo et al., 2018; Sharma et al., 2019; Stankovic, 2020; Mishra et al., 2021). Hyptis suaveolens (L.) Poit. is a perennial herb known in Mexico as donkey's herb (hierba del burro), native to tropical America but currently with pantropical distribution (Padalia et al., 2015). Studies have reported several biological activities of $H$. suaveolens, such as sedative, diuretic, antispasmodic, anti-inflammatory, among others (Mabberley, 1990; Singh et al., 1992; Mishra et al., 2021). In particular the essential oils obtained from its leaves have antimicrobial activity, finding mainly mono- and sesquiterpenes, and their oxygenated derivatives (Mishra et al., 2021). The effectiveness of extracts and essential oils of $H$. suaveolens as antibacterial has been reported, focusing on bacteria with clinical importance (Ngozi et al., 2014; Sánchez-Aguirre et al., 2020; Mishra et al., 2021), and few studies have been conducted against microorganisms of agroeconomic interest (Sharma and Tripathi, 2008; Pachkore et al., 2011). As it is known, the use of synthetic pesticides for the control of plant pathogens represents a large problem to the environment and human health, which has led to the search for safer, natural and more friendly alternatives (Oluwaseun-Adetunji et al., 2019). Most of the phytochemistry studies in polar extracts (methanolic, ethanolic and aqueous) are mainly focused on total determinations, such as total content of phenolics, flavonoids, alkaloids, and saponins, among other chemical groups (Edeoga et al., 2006; Ngozi et al., 2014; Asha et al., 2015; Azhagu-Raj et al., 2017; Sánchez-Aguirre et al., 2020; Mishra et al., 2021; Yada et al., 2021). In addition, some individual phenolic compounds have been reported, including quercetin, apigenin, chlorogenic acid and rosmarinic acid, among others (Prawatsri et al., 2013; Bezerra et al., 2017; Hsu et al., 2019; Tang et al., 2019). The lack of information about the identity of bioactive compounds present in polar extracts brought us to conceive the goals of this research, which includes the identification and quantification of phenolic compounds from a methan- olic extract of $H$. suaveolens leaves and the determination of its antimicrobial activity against Chryseobacterium sp. and Pseudomonas sp., two bacteria with agroeconomic importance (San Martín-Romero et al., 2014; Martins et al., 2018).

\section{Materials and Methods}

\section{Collection of plant material}

The aerial parts of $H$. suaveolens were collected in the community La Tinaja, Veracruz, Mexico, with coordinates $19^{\circ} 31^{\prime} 00.1^{\prime \prime} \mathrm{N}, 96^{\circ} 45^{\prime} 00.0^{\prime \prime} \mathrm{W}$ in September 2014 and January 2017. A reference specimen was deposited with the voucher number Oscar Sánchez-Aguirre number 1 in the herbarium CORU "Jerzy Rzedowski Rotter" of the Faculty of Biological and Agricultural Sciences of the Universidad Veracruzana, Mexico.

\section{Extraction process}

The plant material was dried in an oven at $45^{\circ} \mathrm{C}$ for 30 hours and then milled with a mortar and pestle to obtain a fine dry powder. The methanolic extract was obtained using an accelerated solvent extractor (Dionex, ASE 350, Dionex Corporation, Sunnyvale, California, USA) as previously reported (Monribot-Villanueva et al., 2019). Consequently, $21 \mathrm{~g}$ of the dried material was mixed with $7 \mathrm{~g}$ of diatomaceous earth (Thermo Scientific, Waltham, Massachusetts, USA), and placed in seven $34 \mathrm{ml}$ cells (4 g/cell; Thermo Scientific, Waltham, Massachusetts, USA), then extracted with methanol (HPLC grade; Sigma-Aldrich, St. Louis, Missouri, USA), using a single cycle at $60^{\circ} \mathrm{C}$ for 15 minutes. The extracts were combined, and the total volume was measured. One $\mathrm{ml}$ aliquots was stored at $-80^{\circ} \mathrm{C}$ in an ultra-low temperature freezer (Thermo Scientific, Waltham, Massachusetts, USA) for phenolic compounds determination. The solvent was evaporated under reduced pressure at $40{ }^{\circ} \mathrm{C}$ (rotatory evaporator $\mathrm{R}-\mathrm{II}, \mathrm{BUCHI}$, Flawil, Switzerland). The methanolic extract of $H$. suaveolens leaves was evaluated in an antimicrobial assay at different concentrations from 0.125 to $21 \mathrm{mg} / \mathrm{ml}$.

\section{Determination of antibacterial activity}

The Gram-positive strains Chryseobacterium sp. and Pseudomonas sp. were kindly supplied by Dr. Mauricio Luna Rodríguez from the Faculty of Agricultural Sciences of the Universidad Veracruzana (Xalapa, Mexico). The Chryseobac- 
terium sp. strain was isolated from plants of Sechium edule (Jacq.) Sw. showing necrosis of the leaves. The fruit of Sechium edule (chayote; Cucurbitaceae) is a highly appreciated food in Mexico for its nutritional and functional values that include a good source of starch and vitamins, such as ascorbic and folic acids, thiamine, riboflavin and pyridoxine (San Martín-Romero et al., 2014). Pseudomonas sp. is a wellknown phytopathogenic bacterium that infects many different crops like tobacco, potato, tomato, banana, among others, causing bacterial wilt and huge economic losses (Martins et al., 2018). The Pseudomonas sp. strain used in this study was isolated from damaged plants of Luffa cylindrica M. Roem. Both bacterial strains have been previously reported (Ramírez-Reyes et al., 2014; 2018; 2019).

Strains were kept in King agar B (Sigma-Aldrich, St. Louis, Missouri, USA) and incubated in darkness at $27^{\circ} \mathrm{C} \pm 2$ ${ }^{\circ} \mathrm{C}$ for 24 hours in a heating oven (Binder $\mathrm{GmbH}$, Tuttlingen, Germany). For the antimicrobial test, bacterial suspensions in sterile water were prepared and adjusted to a turbidity of 0.5 according to the McFarland scale (approximately 1.5 $\times 10^{8}$ colony-forming units per $\mathrm{ml}$ ). The minimum inhibitory concentrations (MICs) were determined by the microdilution method using microplates of 96 wells of $400 \mu$ l each, according to the literature (Ramírez-Reyes et al., 2019). As negative control for the antibacterial assays, $15 \%$ and $10 \%$ of dimethyl sulfoxide (DMSO; Sigma-Aldrich, St. Louis, Missouri, USA) aqueous solution were used for Chryseobacterium sp. and Pseudomonas sp., respectively. The antibiotics oxytetracycline (Sigma-Aldrich, St. Louis, Missouri, USA) and chloramphenicol (Sigma-Aldrich, St. Louis, Missouri, USA) were used as positive controls in the antibacterial assays. The previously mentioned antibiotics were dissolved in water at concentrations of $1,0.50,0.25$ and $0.125 \mathrm{mg} / \mathrm{ml}$. The methanolic extract of $H$. suaveolens leaves was tested at concentrations of $21,19,16,13,10,9,8,7,6,5,3,2,1,0.50,0.25$ and 0.125 $\mathrm{mg} / \mathrm{ml}$. Bacterial solution (10 $\mu$ l), Luria-Bertani (LB; Sigma-Aldrich, St. Louis, Missouri, USA) broth $(110 \mu \mathrm{l})$ and the treatment $(80 \mu \mathrm{l})$ were added in each well. In the growth control treatment, only bacterial suspension (10 $\mu$ ) and LB broth $(190 \mu \mathrm{l})$ were added. The assays were performed in triplicate. The microplates were incubated at $27 \pm 2{ }^{\circ} \mathrm{C}$ for 24 hours in a heating oven (Binder, Tuttlingen, Germany). The MIC of each treatment was the lowest concentration at which turbidity was not observed in the well. Afterwards, an aliquot of 10 $\mu \mathrm{l}$ of the wells without turbidity was streaked on King agar B (Sigma-Aldrich, St. Louis, Missouri, USA) and incubated at $27 \pm 2{ }^{\circ} \mathrm{C}$ for 24 hours in a heating oven (Binder $\mathrm{GmbH}$, Tuttlingen, Germany). The minimum bactericidal concentration (MBC) was determined as the lowest concentration that did not generate visible bacterial growth according to the literature (Ramírez-Reyes et al., 2019).

\section{Identification and quantification of phenolic compounds}

We performed a phenolics profiling to identify and quantify bioactive compounds of this chemical category. The methanolic antibacterial extract was analyzed on an ultra-high resolution liquid chromatography coupled to a triple quadrupole mass spectrometer (1290-6460, Agilent Technologies, Santa Clara, California, USA), using a dynamic multiple reaction monitoring method (dMRM) according to previous reports of our research group (Juárez-Trujillo et al., 2018; Monribot-Villanueva et al., 2019). Forty-eight phenolic compounds were searched. The compounds chlorogenic acid, caffeic acid and naringenin were determined in negative mode and their MRM transitions were 353.08>191.05, 179>135 and $271.06>151$, respectively. Vanillin, quercetin-3-O-glucoside, rutin, kaempferol-3-O-glucoside, rosmarinic acid, quercetin, apigenin, kaempferol, hesperetin, nordihydroguaiaretic acid and kaempferide were determined in positive mode and their MRM transitions were 153>93, 465.2>303.04, $611.16>465.1$, 449.1>287.05, 361.09>163.04, 303.05>153.1, $271.06>153.01,287.05>153.02,303.09>177.05,303.16>193.12$ and 301.07>258.05, respectively. For quantification, a calibration curve was constructed from 1 to $9 \mu \mathrm{M}$ for each phenolic compound. A linear regression was applied obtaining $\mathrm{R}^{2}$ values higher than 0.99 for each compound. Each sample was injected by triplicate.

\section{Results}

\section{Determination of antibacterial activity}

The extract only exhibited antibacterial activity against Chryseobacterium sp. at the highest concentration tested, determining the MIC value of $21 \mathrm{mg} / \mathrm{ml}$ (Table 1). An aliquot was streaked on King agar B (Sigma-Aldrich, St. Louis, Missouri, USA) and growing bacteria were not observed following in- 
cubation, determining the $\mathrm{MBC}$ value as $21 \mathrm{mg} / \mathrm{ml}$ (Table 1). Unfortunately, the extract did not exhibit activity against the phytopathogenic Pseudomonas sp. (Table 1).

\section{Identification and quantification of phenolic compounds}

Once determined the antimicrobial activity of the methanolic extract of $H$. suaveolens leaves, we identified and quantified 14 phenolic compounds by a dMRM method using a simultaneous analysis with 48 authentic standards. The phenolic compounds identified by coelution with reference compounds were caffeic acid, vanillin, rutin, quercetin-3-O-glucoside, kaempferol-3-O-glucoside, rosmarinic acid, quercetin, kaempferol, chlorogenic acid, naringenin, apigenin, hesperetin, nordihydroguaiaretic acid and kaempferide (Fig. 1). Rosmarinic acid exhibited the highest concentration with a concentration higher than $2700 \mu \mathrm{g}$ of compound per gram of dried weight (DW) material $(\mu \mathrm{g} / \mathrm{g}$ ), followed by quercetin-3-O-glucoside and rutin with concentrations higher than $100 \mu \mathrm{g} / \mathrm{g}$ DW (Table 2). Caffeic acid and kaempferol-3-O-glucoside exhibited a content higher than $30 \mu \mathrm{g} / \mathrm{g}$ DW followed by quercetin, kaempferol, vanillin, chlorogenic acid, naringenin, apigenin, hesperetin, nordihydroguaiaretic acid and kaempferide with concentrations less than $20 \mu \mathrm{g} / \mathrm{g}$ DW (Table 2).

\section{Discussion}

Hyptis suaveolens is commonly used in the traditional medicine in different countries in America, Asia and Africa, due to its properties as sedative, diuretic, antispasmodic, antiinflammatory, anti-catarrhal, anti-cancer and antimicrobial agent, among others (Li et al., 2020; Mishra et al., 2021).
In our study, we evaluated the antimicrobial activity of the methanolic extract against two phytopathogenic bacteria that affect economical important crops. We determined that the extract only exhibited activity at the highest concentration tested against Chryseobacterium sp., which is known for damaging Sechium edule (San Martín-Romero et al., 2014). Mexico, particularly the state of Veracruz, is the main worldwide producer and exporter of $S$. edule fruit, known as chayote, and its production is severely affected by phytopathogens (Olguín-Hernández et al., 2013; San Martín-Romero et al., 2014). Chayote is commonly used as ingredient in food, but has gained recognition for its nutritional and bio-functional properties (Vieira et al., 2019; Uuh-Narváez et al., 2021). Due to the economic importance of $S$. edule, we have conducted several efforts to search for safer and natural alternatives to control the phytopathogenic Chryseobacterium sp. (Ramírez-Reyes et al., 2018; 2019). The antimicrobial activity against Chryseobacterium sp. of extracts obtained from the aerial parts of 16 plant species were previously determined (Ramírez-Reyes et al., 2018; 2019). The methanolic extracts of Leandra cornoides (Schltdl. \& Cham.) Cogn. and Turpinia insignis (Kunth) Tul. and the ethyl acetate extract of Magnolia vovidesii A. Vázquez, Domínguez-Yescas \& L. Carvajal exhibited antimicrobial activity against Chryseobacterium sp. (Ramírez-Reyes et al., 2018; 2019; Table 3).

The antibacterial activity against Chryseobacterium sp. exhibited by the methanolic extract of $H$. suaveolens (Table 1,3 ) is low compared to that exhibited by the methanolic extracts of $L$. cornoides and $T$. insignis against this bacterium (Ramírez-Reyes et al., 2019; Table 3). In addition, the antimicrobial activity of the methanolic extract of $H$. suaveolens leaves is low compared to that exhibited by the ethanolic

Table 1: Antibacterial effect of extracts and antibiotics against the phytopathogens Chryseobacterium sp. and Pseudomonas sp. MIC=Minimum Inhibitory Concentration, $\mathrm{MBC}=$ Minimum Bactericidal Concentration, ND=Not determined.

\begin{tabular}{llcc}
\hline Pathogenic bacteria & Treatment & MIC (mg/ml) & MBC (mg/ml) \\
\hline Chryseobacterium sp. & Hyptis suaveolens (L.) Poit. & 21 & 21 \\
& Oxytetracycline & 0.25 & ND \\
& Chloramphenicol & 0.50 & ND \\
Pseudomonas sp. & Hyptis suaveolens (L.) Poit. & $>21$ & ND \\
& Oxytetracycline & 0.50 & ND \\
& Chloramphenicol & 0.50 & ND \\
\hline
\end{tabular}




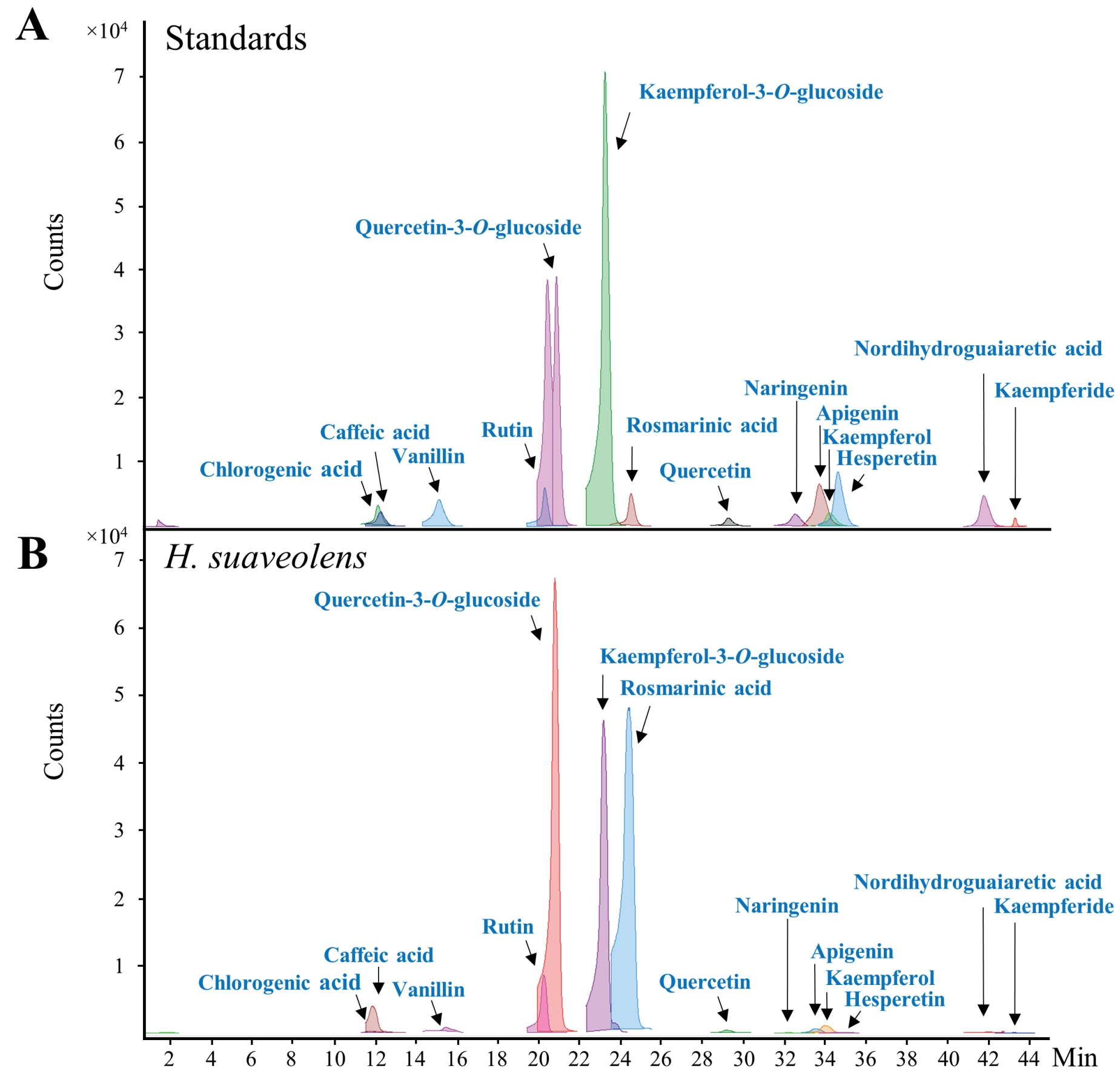

Figure 1: Representative chromatograms of: A. authentic phenolic standards mixture and B. the methanolic extract of leaves of Hyptis suaveolens (L.) Poit.

extract of $H$. suaveolens tested against multiple pathogenic bacteria, including Pseudomonas aeruginosa (Schroeter 1872) Migula 1900 in a concentration of $75-100 \mu \mathrm{g} / \mathrm{ml}$ (Pachkore et al., 2011; Malar et al., 2012). The hydromethanolic extract of Hyptis atrorubens Poit. exhibited higher antimicrobial activity against $P$. aeruginosa, inhibiting the micro- bial growth in a concentration of $0.3-2.5 \mathrm{mg} / \mathrm{ml}$ (Abedini et al., 2013). However, the present work is the first report of the activity of $H$. suaveolens against the phytopathogenic bacterium Chryseobacterium sp., which represents a new venue to explore the biological activities of this species as potential control agent in important crops. 
Table 2: Phenolic compounds present in the methanolic extract from the aerial parts of Hyptis suaveolens (L.) Poit. Concentrations are expressed in $\mu \mathrm{g}$ of compound per gram of dried material. The average value of three replicates \pm standard deviation is shown. ${ }^{*}$ Concentration below the limit of quantitation.

\begin{tabular}{lcc}
\hline Compound & Retention time $(\mathrm{min})$ & Concentration $(\mu \mathrm{g} / \mathrm{g})$ \\
\hline Rosmarinic acid & 24.5 & $2736.03 \pm 33.65$ \\
Quercetin-3-O-glucoside & 20.9 & $226.54 \pm 7.50$ \\
Rutin & 20.4 & $159.09 \pm 6.52$ \\
Caffeic acid & 12.5 & $53.86 \pm 1.47$ \\
Kaempferol-3-O-glucoside & 23.3 & $34.62 \pm 1.37$ \\
Kaempferol & 34.2 & $18.03 \pm 1.27$ \\
Quercetin & 29.4 & $10.46 \pm 0.84$ \\
Vanillin & 15.1 & $2.79 \pm 0.10$ \\
Chlorogenic acid* & 11.9 & $2.94 \pm 0.33$ \\
Hesperetin* & 34.8 & $1.77 \pm 0.01$ \\
Nordihydroguaiaretic acid* & 41.9 & $1.66 \pm 0.02$ \\
Apigenin* & 33.4 & $0.62 \pm 0.12$ \\
Naringenin* & 32.0 & $0.51 \pm 0.01$ \\
Kaempferide* & 43.2 & $0.50 \pm 0.01$ \\
\hline
\end{tabular}

Table 3: Antibacterial effect of extracts against Chryseobacterium sp. 1: Ramírez-Reyes et al., 2018; 2: Ramírez-Reyes et al., 2019; 3: this study. MIC=Minimum Inhibitory Concentration.

\begin{tabular}{|c|c|c|c|}
\hline Species & Tissue & Solvent & MIC \\
\hline Magnolia vovidesii A. Vázquez, Domínguez-Yescas \& L. Carvajal ${ }^{1}$ & Polyfollicles & Ethyl acetate & $400 \mu \mathrm{g} / \mathrm{ml}$ \\
\hline Leandra cornoides (Schltdl. \& Cham.) Cogn. ${ }^{2}$ & Leaves & Methanol & $400 \mu \mathrm{g} / \mathrm{ml}$ \\
\hline Turpinia insignis (Kunth) Tul. ${ }^{2}$ & Leaves & Methanol & $400 \mu \mathrm{g} / \mathrm{ml}$ \\
\hline Hyptis suaveolens (L.) Poit. ${ }^{3}$ & Leaves & Methanol & $21,000 \mu \mathrm{g} / \mathrm{ml}$ \\
\hline
\end{tabular}

Regarding the identified bioactive compounds, rosmarinic acid is a well-known bioactive phenolic identified in several plant families including Lamiaceae (Petersen, 2013) and specifically in H. suaveolens (Prawatsri et al., 2013; Tang et al., 2019). In addition, other phenolic compounds such as simple phenolic acids, phenylpropanoids, flavonoids and tannin's precursors and derivatives have been reported in $H$. suaveolens (Prawatsri et al., 2013; Bezerra et al., 2017; Hsu et al., 2019; Tang et al., 2019). In figure 2, we summarize the information regarding the phenolic content reported in H. suaveolens. In our study, we identified and quantified 14 phenolic compounds in the methanolic extract of $\mathrm{H}$. suaveolens leaves (Table 2). Besides identification, we quantified for the first time the endogenous content of rosmarinic acid in $\mathrm{H}$. suaveolens leaves, exhibiting the highest level (Table 2). The therapeutic potential on human health for rosmarinic acid is highlighted considering the many biological activities previously reported, including anti-inflammatory, antioxidant, astringent, anti-diabetic, anti-allergic, antimutagenic, antidepressant, anti-aging, antibacterial and antiviral (Petersen, 2013; Alagawany et al., 2017; Nadeem et al., 2019; Trócsányi et al., 2020). Regarding its antimicrobial activity, 
rosmarinic acid exhibited antibacterial activity against wild strains of Bacillus subtilis (Ehrenberg 1835) Cohn 1872, Micrococcus luteus (Schroeter 1872) Cohn 1872, Escherichia coli (Migula 1895) Castellani and Chalmers 1919 and P. aeruginosa (Kuhnt et al., 1995), as well as against important human pathogen bacteria like methicillin-resistant Staphylococcus aureus (Rosenbach 1884), whose infections cause sepsis, toxic shock syndrome and necrotizing pneumonia (Ekambaram et al., 2016).

Along with rosmarinic acid, most of the phenolic compounds identified in $H$. suaveolens belong to the flavonoids group. We identified for the first time naringenin (Table 2), an initial precursor for the biosynthesis of downstream flavonoids such as apigenin, hesperetin, catechin, quercetin, kaempferol and their glycosylated derivatives (Fig. 2). Kaempferide, kaempferol-3-O-glucoside and hesperetin are being reported for the first time in $H$. suaveolens (Fig. 2, Table 2). Previous studies have shown the presence of phenolic ac- ids like gallic, ellagic, caffeic, chlorogenic and 4-hydroxybenzoic acids in $H$. suaveolens (Bezerra et al., 2017; Hsu et al., 2019). We identified and quantified caffeic and chlorogenic acids and we are reporting for the first time vanillin, the precursor of 4-hydroxybenzoic acid (Fig. 2, Table 2). Moreover, nordihydroguaiaretic acid is a lignan that is also reported for the first time here (Table 2). Considering the global results, our study contributes to the phytochemical knowledge of $H$. suaveolens. The presence of these phenolic compounds matched with the antioxidant activity previously reported for this plant (Ngozi et al., 2014; Chigor, 2018; Sánchez-Aguirre et al., 2020) and they could be responsible in part for the antimicrobial activity observed against Chryseobacterium sp. (Table 1). Interestingly, in closely related species such as $H$. atrorubens, the phenolic compounds rosmarinic acid, methyl rosmarinate, hyperoside and quercetin-3-O-glucoside are responsible for the antimicrobial activity (Abedini et al., 2013). Rosmarinic acid and quercetin-3-O-glucoside

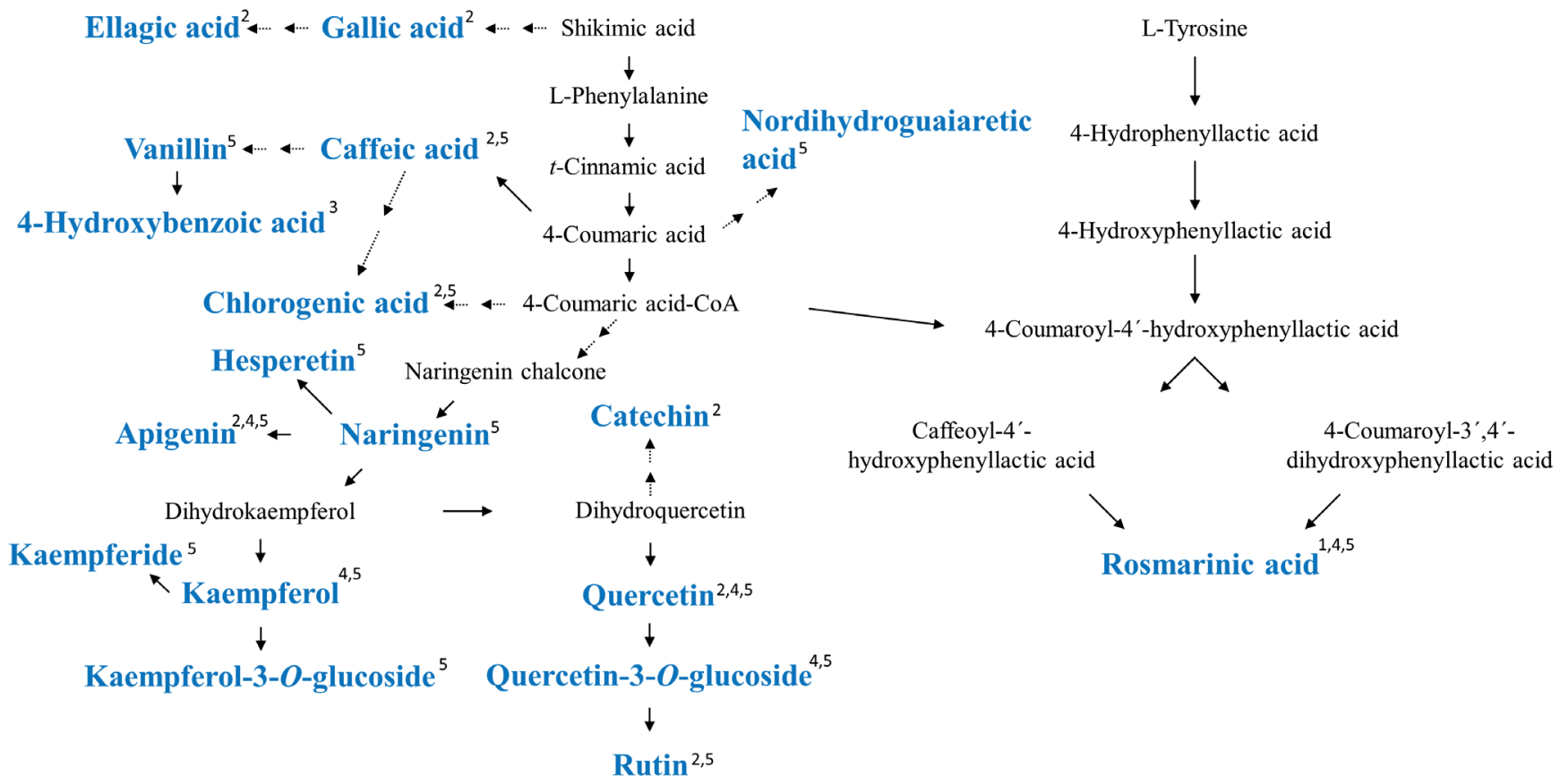

Figure 2: Reconstruction proposal of the phenolic biosynthesis pathway in Hyptis suaveolens (L.) Poit. based on our results and the information reported in the Kyoto Encyclopedia of Genes and Genomes database (Kanehisa et al., 2016) and in previous reports (1: Prawatsri et al., 2013; 2: Bezerra et al., 2017; 3: Hsu et al., 2019; 4: Tang et al., 2019; 5: this study; Trócsányi et al., 2020). Solid arrows indicate one-step reaction while dotted arrows indicated multi-steps reaction. The compounds identified in $\mathrm{H}$. suaveolens are indicated in blue. 
were also identified and quantified in $H$. suaveolens (Table 2). On the other hand, the antimicrobial activity against Chryseobacterium sp. of 12 phenolic compounds identified in the methanolic extracts of aerial parts of $L$. cornoides and T. insignis was previously determined (Ramírez-Reyes et al., 2019). Ellagic, gallic, gentisic, vanillic, 4-hydroxybenzoic, caffeic, ferulic, and 4-coumaric acids did not exhibit antimicrobial activity against Chryseobacterium sp. (Ramírez-Reyes et al., 2019). In contrast, vanillin (MIC value of $0.8 \mathrm{mg} / \mathrm{ml}$ ), $t$-cinnamic acid (MIC value of $0.4 \mathrm{mg} / \mathrm{ml}$ ), scopoletin (MIC value of $0.8 \mathrm{mg} / \mathrm{ml}$ ), and umbelliferone (MIC value of $0.8 \mathrm{mg} / \mathrm{ml}$ ) exhibited antimicrobial activity against Chryseobacterium sp. (Ramírez-Reyes et al., 2019). Vanillin was also identified in the methanolic extract of $H$. suaveolens at a concentration of $2.79 \mu \mathrm{g} / \mathrm{g}$ DW (Table 2) and could be responsible of the antimicrobial activity against Chryseobacterium sp. Further studies are needed to determine which other phenolic compounds contribute to the antibacterial activity displayed by the methanolic extract of $H$. suaveolens.

\section{Conclusions}

The methanolic extract of the aerial parts from Hyptis suaveolens exhibited antibacterial activity against Chryseobacterium sp., an opportunist bacterium that damages crops. As a result of the search of bioactive metabolites, 14 phenolic compounds were identified and quantified, and six of them are being reported for the first time in $\mathrm{H}$. suaveolens. Further studies are needed to evaluate the activity of identified compounds against Chryseobacterium sp.

\section{Author contributions}

JAGA and MGC conceived and designed the study. JMCL, IBL, and FRF developed the experimental work in the lab. FRF performed the taxonomic identification. JLMV performed the acquisition and interpretation of mass spectrometry data. EMCM contributed to the analysis and interpretation of the antimicrobial assays. IBL, JAGA and JLMV wrote the manuscript. All authors contributed to the discussion and revision of the final version of the manuscript.

\section{Funding}

This research was funded by PRONACES-CONACYT (Consejo Nacional de Ciencia y Tecnología, Grant 316998) which al- lowed the maintenance and prope operativity of the liquid chromatography mass spectrometry platform used.

\section{Acknowledgements}

We thank CONACYT for the funding granted. We also deeply thank the anonymous reviewers and the editorial committee who contributed to substantially improve the manuscript.

\section{Literature cited}

Abedini, A., V. Roumy, S. Mahieux, M. Biabiany, A. StandaertVitse, C. Rivière, S. Sahpaz, F. Bailleul, C. Neut and T. Hennebelle. 2013. Rosmarinic acid and its methyl ester as antimicrobial components of the hydromethanolic extract of Hyptis atrorubens Poit. (Lamiaceae). Evidence-Based Complementary and Alternative 2013: 604536. DOI: http:// doi.org/10.1155/2013/604536

Alagawany, M., M. E. A. El-Hack, M. R. Farag, M. Gopi, K. Karthik, Y. S. Malik and K. Dhama. 2017. Rosmarinic acid: modes of action, medicinal values and health benefits. Animal Health Research Reviews 18(2): 167-176. DOI: https://doi. org/10.1017/S1466252317000081

Asha, D., L. Mathew and K. S. Rishad. 2015. Evaluation of HPTLC fingerprints of flavonoids and antioxidant activity of selected medicinal plants of Lamiaceae Family. International Journal of Pharmacognosy and Phytochemical Research 7(2): 240245.

Azhagu-Raj, R., M. Gomathi, A. Prakasam, K. Priya, V. Narayanayyar, P. Mahesha and S. Siva-Subramanian. 2017. Preliminary phyto-chemical analysis and biological activity of Hyptis suaveolens (L.) (Lamiaceae). The Pharma Innovation Journal 6(7): 1032-1038.

Bezerra, J. W. A., A. R. Acosta, M. A. P. da Silva, M. I. Rocha, A. A. Boligon, J. B. T. da Rocha, L. M. Barros and J. P. Kamdem. 2017. Chemical composition and toxicological evaluation of Hyptis suaveolens (L.) Poiteau (LAMIACEAE) in Drosophila melanogaster and Artemia salina. South African Journal of Botany 113: 437-442. DOI: https://doi.org/10.1016/j. sajb.2017.10.003

Chigor, C. B. 2018. Phytochemical constituent and antioxidant potential of Hyptis suaveolens (L.) Poit leaf. Tropical Journal of Applied Natural Sciences 2: 55-60. DOI: https://doi. org/10.25240/TJANS.2018.2.2.07 
Edeoga, H. O., G. Omosun and L. C. Uche. 2006. Chemical composition of Hyptis suaveolens and Ocimum gratissimum hybrids from Nigeria. African Journal of Biotechnology 5(10): 892-895.

Ekambaram, S. P., S. S. Perumal, A. Balakrishnan, N. Marappan, S. S. Gajendran and V. Viswanathan. 2016. Antibacterial synergy between rosmarinic acid and antibiotics against methicillinresistant Staphylococcus aureus. Journal of Intercultural Ethnopharmacology 5: 358. DOI: https://doi.org/10.5455/ jice.20160906035020

Hsu, F. C., S. F. Tsai and S. S. Lee. 2019. Chemical investigation of Hyptis suaveolens seed, a potential antihyperuricemic nutraceutical, with assistance of HPLC-SPE-NMR. Journal of Food and Drug Analysis 27(4): 897-905. DOI: https://doi. org/10.1016/j.jfda.2019.05.006

Juárez-Trujillo, N., J. L. Monribot-Villanueva, V. M. JiménezFernández, R. Suárez-Montaño, A. S. Aguilar-Colorado, J. A. Guerrero-Analco and M. Jiménez. 2018. Phytochemical characterization of Izote (Yucca elephantipes) flowers. Journal of Applied Botany and Food Quality 91: 202-210. DOI: https://doi.org/10.5073/JABFQ.2018.091.027

Kanehisa, M., Y. Sato, M. Kawashima, M. Furumichi and M. Tanabe. 2016. KEGG as a reference resource for gene and protein annotation. Nucleic Acids Research 44(D1): D457-D462. DOI: https://doi.org/10.1093/nar/gkv1070

Kuhnt, M., A. Pröbstle, H. Rimpler, R. Bauer and M. Heinrich. 1995. Biological and pharmacological activities and further constituents of Hyptis verticillata. Planta Medica 61(3): 227232. DOI: https://doi.org/10.1055/s-2006-958061

Li, R., G. Tang, X. Liu, J. Li, D. Wang and S. Ji. 2020. An ethnopharmacological review of Hyptis suaveolens (L.) Poit. Tropical Journal of Pharmaceutical Researh 19(7): 15411550. DOI: https://doi.org/10.4314/tjpr.v19i7.29

Luzuriaga-Quichimbo, C. X., J. Blanco-Salas, C. E. Cerón-Martínez, M. S. Stankovic and T. Ruiz-Téllez. 2018. On the possible chemical justification of the ethnobotanical use of Hyptis obtusiflora in Amazonian Ecuador. Plants 7(4): 104. DOI: https://doi.org/10.3390/plants7040104

Mabberley, D. J. 1990. The plant book. Cambridge University Press, London, UK.

Malar, R. J. J. T., S. L. Sushna, M. Johnson, N. Janakiraman and R. J. J. T. Ethal. 2012. Bio-efficacy of the leaves extracts of Hyptis suaveolens (L.) Poit. against the fish pathogens. International Journal Life Science Pharma Research 2(1): 128-133.

Martins, P. M. M., M. V. Merfa, M. A. Takita and A. A. De Souza. 2018. Persistence in phytopathogenic bacteria: Do we know enough? Frontiers in Microbiology 9: 1099. DOI: https://doi. org/10.3389/fmicb.2018.01099

Mishra, P., S. Sohrab and K. Mishra. 2021. A review on the phytochemical and pharmacological propierties of Hyptis suaveolens (L.) Poit. Future Journal of Pharmaceutical Sciences 7: 65 (1-11). DOI: https://doi.org/10.1186/s43094021-00219-1

Monribot-Villanueva, J. L., J. M. Elizalde-Contreras, M. Aluja, A. Segura-Cabrera, A. Birke, J. A. Guerrero-Analco and E. Ruiz-May. 2019. Endorsing and extending the repertory of nutraceutical and antioxidant sources in mangoes during postharvest shelf life. Food Chemistry 285: 119-129. DOI: https://doi.org/10.1016/j.foodchem.2019.01.136

Nadeem, M., M. Imran, T. A. Gondal, A. Imran, M. Shahbaz, R. M. Amir, M. W. Sajid, T. B. Qaisrani, M. Atif, G. Hussain, B. Salehi, E. A. Ostrander, M. Martorell, J. Sharifi-Rad, W. C. Cho and N. Martins. 2019. Therapeutic potential of rosmarinic acid: a comprensive review. Applied Sciences 9(15): 3139-3162. DOI: https://doi.org/10.3390/app9153139

Ngozi, L., N. Ugochukwu, P. Udeozo-Ifeoma, E. Anarado-Charity and I. Egwuatu-Chinyelu. 2014. The Efficacy of Hyptis suaveolens: A Review of Its Nutritional and Medicinal Applications. European Journal of Medicinal Plants 4(6): 661-674.

Olguín-Hernández, G., G. Valdovinos-Ponce, J. Cadena-Íñiguez and M. L. Arévalo-Galarza. 2013. Etiology of Chayote (Sechium edule) wilting plants in the state of Veracruz. Revista Mexicana de Fitopatología 31(2): 161-169.

Oluwaseun-Adetunji, C. C. Egbuna, H. Tijjani, D. Adom, L. K. Tawfeeq Al-Ani and K. C. Patrick-Iwuanyanwu. 2019. Homemade Preparations of Natural Biopesticides and Applications. In: Egbuna, C. and B. Sawicka (eds.). Natural Remedies for Pest, Disease and Weed Control. Ed. Academic Press. Cambridge, USA. Pp. 179-185. DOI: https://doi.org/10.1016/B978-0-12819304-4.00015-4

Pachkore, G. L., D. A. Dhale and A. N. Dharasurkar. 2011. Antimicrobial and phytochemical screening of Hyptis suaveolens (L. Poit) Lamiaceae. International Multidisciplinary Research Journal 1(4): 03-03. 
Padalia, H., V. Srivastava and S. P. S. Kushwaha. 2015. How climate change might influence the potential distribution of weed, bushmint (Hyptis suaveolens)? Environmental Monitoring and Assessment 187: 210. DOI: https://doi.org/10.1007/ s10661-015-4415-8

Petersen, M. 2013. Rosmarinic acid: new aspects. Phytochemistry Reviews 12: 207-227. DOI: https://doi.org/10.1007/s11101$013-9282-8$

Prawatsri, S., A. Suksamrarn, A. Chindaduang and T. Rukachaisirikul. 2013. Abietane Diterpenes from Hyptis suaveolens. Chemistry and Biodiversity 10(8): 1494-1500. DOI: https://doi.org/10.1002/cbdv.201200213

Ramírez-Reyes, T., M. Luna-Rodríguez, J. C. Noa-Carrazana, F. DíazFleischer, L. R. Sánchez-Velásquez and N. Flores-Estévez. 2014. Influence of season and organ on antibacterial activity of Magnolia dealbata Zucc. against two phytopathogenic bacteria. Chemistry and Ecology 31(1): 47-52. DOI: https:// doi.org/10.1080/02757540.2014.932779

Ramírez-Reyes, T., J. L. Monribot-Villanueva, O. D. JiménezMartínez, A. S. Aguilar-Colorado, I. Bonilla-Landa, N. FloresEstévez, M. Luna-Rodríguez and J. A. Guerrero-Analco. 2018. Sesquiterpene lactones and phenols from polyfollicles of Magnolia vovidessi and their antimicrobial activity. Natural Product Communications 13: 521-525. DOI: https://doi.org /10.1177/1934578X1801300502

Ramírez-Reyes, T. I., A. S. Aguilar-Colorado, D. L. Murrieta-León, L. S. Licona-Velázquez, I. Bonilla-Landa, C. Durán-Espinosa, S. Avendaño-Reyes, J. L. Monribot-Villanueva and J. A. Guerrero-Analco. 2019. Identification of antibacterial phenolics in selected plant species from mexican cloud forest by mass apectrometry dereplication. Chemistry and Biodiversity 16(4): e1800603. DOI: https://doi.org/10.1002/ cbdv.201800603

San Martín-Romero, E., M. Luna-Rodríguez, F. Díaz-Fleischer, L. G. Iglesias-Andreau, J. C. Noa-Carranza, N. Flores-Estévez and D. Barceló-Antemate. 2014. A strain of Chryseobacterium sp. isolated from necrotic leaf tissue of chayote (Sechium edule Jacq). International Research Journal of Biological Sciences 3(4): 52-60.

Sánchez-Aguirre, O., A. Cruz-Navarro, M. Guevara-Valencia, E. Rengifo-Salgadoand G.S. Vargas-Arana. 2020. Phytochemical screening, antioxidant activity and in vitro biological evaluation of leave extracts of Hyptis suaveolens (L.) from south of Mexico. South African Journal of Botany 128: 6266. DOI: https://doi.org/10.1016/j.sajb.2019.10.016

Sharma, A., H. P. Singh, D. R. Batish and R. K. Kohli. 2019. Chemical profiling, cytotoxicity and phytotoxicity of foliar volatiles of Hyptis suaveolens. Ecotoxicology and Environmental Safety 171:863-870. DOI: https://doi.org/10.1016/j. ecoenv.2018.12.091

Sharma, N. and A. Tripathi. 2008. Integrated management of postharvest Fusarium rot of gladiolus corms using hot water, UV-C and Hyptis suaveolens (L.) Poit. essential oil. Postharvest Biology and Technology 47(2): 246-524. DOI: https://doi.org/10.1016/j.postharvbio.2007.07.001

Singh, G., R. N. Upadhyay and G. P. Rao. 1992. Fungitoxic activity of volatile oil of Hyptis suaveolens. Fitoterapia 63:462-465.

Stankovic, M. (ed.). 2020. Lamiaceae Species Biology, Ecology and Practical Uses. Multidisciplinary Digital Publishing Institute (MDPI). Basel, Switzerland. 25 pp. DOI: https://doi. org/10.3390/books978-3-03928-419-1

Tang, G., X. L., X. Liu, X. Gong, X. Lin, X. Lai, D. Wang and S. Ji. 2019. Studies on the Chemical Compositions of Hyptis suaveolens (L.) Poit. Journal of Serbian Chemical Society 84(3): 245252. DOI: https://doi.org/10.2298/JSC171208078T

Trócsányi, E., Z. György and E. Zámboriné-Németh. 2020. New insights into rosmarinic acid biosynthesis based on molecular studies. Current Plant Biology 23: 100162. DOI: https://doi.org/10.1016/j.cpb.2020.100162

Uuh-Narváez, J. J., M. A. González-Tamayo and M. R. SeguraCampos. 2021. A study on nutritional and functional study properties of Mayan plant foods as a new proposal for type 2 diabetes prevention. Food Chemistry 341(1): 128247. DOI: https://doi.org/10.1016/j.foodchem.2020.128247

Vieira, E. F., O. Pinho, I. M. Ferreira and C. Delerue-Matos. 2019. Chayote (Sechium edule): A review of nutritional composition, bioactivities and potential applications. Food Chemistry 275: 557-568. DOI: https://doi.org/10.1016/j. foodchem.2018.09.146

Yada, D., T. Sivakkumar and N. Srinivas. 2021. Phytochemical evaluation and in-vitro antioxidant potential of whole plant of Hyptis suaveolens. Research Journal of Pharmacy and Technology 14(1): 409-412. DOI: https://doi. org/10.5958/0974-360X.2021.00074.3 